\title{
Effect of fat source, energy level and enzyme supplementation and their interactions on broiler performance
}

\author{
A.M. Abudabos ${ }^{\#}$ \\ Department of Animal Production, College of Food and Agriculture Sciences \\ King Saud University, P.O. Box 2460, Riyadh 11451, Kingdom of Saudi Arabia
}

(Received 18 September 2012; Accepted 21 July 2014; First published online 24 September 2014)

Copyright resides with the authors in terms of the Creative Commons Attribution 2.5 South African Licence.
See: http://creativecommons.org/licenses/by/2.5/za
Condition of use: The user may copy, distribute, transmit and adapt the work, but must recognise the authors and the South African
Journal of Animal Science.

\begin{abstract}
This study was conducted to evaluate the effects of replacing soybean oil (SBO), typical in broiler diets, with a less expensive commercial fat blend, Kofat (KOF). A $2 \times 2 \times 2$ factorial experimental design was used to study the interactions of the two fat sources, SBO and KOF, at two levels of metabolizable energy (ME) (low and normal) with the inclusion or not of an enzyme, Tomoko (TOM), in broiler diets. The broilers were fed ad libitum in cages from 1 to 30 days of age. Two hundred one-day-old male (Ross 308) chicks were distributed among 40 cages with five replicates per treatment, and received a starter diet from 1 to 16 days and a finisher diet for days 17 to 30 . Cumulative feed intake was not influenced by fat source, energy level or TOM supplementation for the starter, finisher or total periods. For the total period ( 1 to 30 days), energy $x$ enzyme interaction was significant for bodyweight gain (BWG) and feed conversion ratio (FCR). The TOM supplementation had a positive effect on the low energy diet and a negative effect on the normal energy diet with respect to BWG and FCR. The TOM enzyme was able to restore the nutritional value in the low energy diet. Fat source had no influence on performance of broilers during the experiment period. It was concluded that KOF as a source of fat and the enzyme, TOM at a rate of $0.05 \%$, can be included in a broiler diet where the ME level has been reduced by $414 \mathrm{~kJ} / \mathrm{kg}$ during the starter and finisher periods.
\end{abstract}

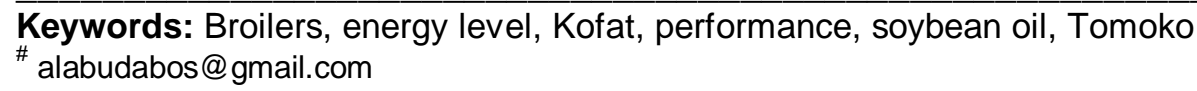

\section{Introduction}

Fats and vegetable oils are frequently included in broiler diets to increase the energy density of the diet, improve efficiency and increase nutrient digestibility in broilers (Baião \& Lara, 2005; Fascina et al., 2009; Monfaredi et al., 2011). Soybean oil (SBO) is the most commonly included fat in broiler diets, but other sources such as corn oil, palm oil, rapeseed oil, sunflower oil, cottonseed oil, coconut oil and beef tallow can be used as energy source, depending on cost and availability (Baião \& Lara, 2005; Barbour et al., 2006). Several studies have been conducted to examine the effect of fat type on broiler performance. Dänicke et al. (1997b) reported a significant effect of fat source (soybean oil vs. tallow) on bodyweight gain (BWG) and feed conversion ratio (FCR) in broilers that received soybean oil-based diets. Conversely, Preston et al. (2001) reported no significant effects of fat source (tallow, soy oil, a tallow : soy oil (2:1) blend) on bird performance.

The value of the various fats and oils depends on price, energy contents, digestibility and absorption (Waldroup et al., 1995). It is well documented that the ratio of saturated to unsaturated fatty acids in the diet influences the digestibility of fat and metabolizable energy (ME) content of fats and fat blends (Wiseman et al., 1991). The high cost of supplemental energy necessitates the optimization of fat inclusion in broiler diets, especially during the finisher period, in which feed consumption is the highest. Consequently, there is great demand for low-priced fat sources in broiler diets.

The bioavailability of nutrients from maize and soybean meal (SBM) is not ideal. Marquardt (1997) reported that maize and SBM are incompletely digested by poultry owing to the presence of non-starch polysaccharides (NSPs), which are considered anti-nutritional factors. Water-soluble NSPs fed to young chicks interfere with the digestion and absorption of other nutrients by increasing the viscosity of digesta in the gut (Ward \& Marquardt, 1983). Xylanase supplementation was noted to increase the digestibility of insoluble pentosans (Dänicke et al., 1997b). 
Several attempts have been made to increase the nutritional value of corn-SBM diets by adding protease and carbohydrases before or after processing (Café et al., 2002; Gracia et al., 2003; Abudabos, 2012). One approach to incorporate enzymes into corn-SBM diets is by changing the nutrient density of the feed to reduce the cost per ton of feed and then, by adding enzymes, restores the nutritional value of the diet. This results in a better performance or at least similar to diets of normal density (Pack \& Bedford, 1997). It was suggested that the enzymes reduce the negative effects of NSPs and improve the digestion of nutrients in the bird.

Several studies have been conducted to examine the interaction between fat source and enzyme inclusion. Dänicke et al. (1997) reported that the performance was higher in broilers that received a SBObased diet that was supplemented with an enzyme compared with unsupplemented tallow-based diets. Significant interactions were reported between dietary fat type and carbohydrase addition (Dänicke et al., 2000). It was established that the enzyme effect depends on fat type included in the diet (Dänicke et al., 1997a; Langhout et al., 1997). However, there is a dearth of information on the interacting effects of fat source, enzyme inclusion and the ME level of the diet.

The objective of the present study was to evaluate the effects on broiler performance by replacing a typical source of oil, SBO, in broiler diets with a cheaper commercial fat blend, Kofat (KOF), using two levels of ME (normal and low), with and without the supplementation of the enzyme, Tomoko (TOM).

\section{Materials and Methods}

Two hundred, one-day-old male Ross 308 broiler chicks, obtained from a commercial hatchery (AlWadi Poultry Farm Co., Riyadh, Saudi Arabia) were used in the study. The chicks had been vaccinated against Marek's disease, Newcastle and infectious bronchitis. The study was conducted under a protocol approved by King Saud University and complies with the current laws of Saudi Arabia.

Typical isoenergetic and isonitrogenous starter $(0-16 \mathrm{~d})$ and finisher $(17-30 \mathrm{~d})$ diets based on maize-SBM diets were formulated in mash form to meet or exceed the recommendations in commercial practice in Saudi Arabia (Table 1). Two sources of fat, SBO and KOF, two levels of TOM enzyme, 0.0\% and $0.05 \%$, and two levels of energy, a normal and subnormal or low level of ME, were applied in a factorial arrangement of eight dietary treatments. The experimental treatments were: T1 = low energy, SBO without TOM; T2 = T1 + 0.05\% TOM; T3 = normal energy, SBO without TOM; T4 = T3 + TOM; T5 = low energy, KOF without TOM; T6 = T5 + 0.05\% TOM; T7 = normal energy, KOF without TOM; T8 = T8 + TOM. The starter diet contained $12.13 \mathrm{MJ} \mathrm{ME} / \mathrm{kg}$ for the low and $12.55 \mathrm{MJ} \mathrm{ME} / \mathrm{kg}$ for the normal diet, while the finisher contained 12.55 MJ ME/kg and 12.97 MJ ME/kg for the low and normal diets, respectively.

Upon arrival, the chicks were sexed, grouped by weight in such a way as to reduce variation in mean bodyweight, and allotted to 40 cages in a four-deck cage system. Each treatment was assigned to five replicate pens with five chicks per cage (50 cm length, $60 \mathrm{~cm}$ width and $36 \mathrm{~cm}$ depth). They received the experimental diets in electrically heated battery brooders with raised wire floors. The birds were maintained on a $24 \mathrm{~h}$ light schedule and ambient temperature and relative humidity were concurrently and continuously recorded at three-hour intervals using two data loggers (HOBO Pro Series Data Logger, Model H08-032-08, Onset Co., USA) inside the chamber. The average temperature and relative humidity for the whole period were $24.95{ }^{\circ} \mathrm{C} \pm 0.26(\mathrm{SD})$ and $26.63 \% \pm 3.30(\mathrm{SD})$, respectively.

Tomoko (Biogenkoji Research Institute, 876-15, Mizobe, Kagoshima, Japan) is a multi-enzyme preparation that is produced by fermentation using Koji-feed (Aspergillus awamori). The activity of the enzyme source was authenticated by the supplier as having minimum levels of acidic protease (10 000 U/g), a-amylase $(40 \mathrm{U} / \mathrm{g})$, pectinase $(30 \mathrm{U} / \mathrm{g})$, phytase $(10 \mathrm{U} / \mathrm{g})$, glucoamylase $(5 \mathrm{U} / \mathrm{g})$, cellulase $(4 \mathrm{U} / \mathrm{g})$ and Aspergillus awamori cells (10 mg/g). Kofat (EcoOils Sdn Bhd, 81700 Pasir Gudang, Johr Darul Takzim, Malaysia) is formulated from a mixture of vegetable oils supplemented with anti-oxidant and lecithin. According to the manufacturer, the fatty acid composition profile of KOF is: myristic acid (C14:0) $6.0 \%$, palmitic acid (C16:0) 30\% - 35\%, stearic acid (18:0) 4.0\% - 5.0\%, oleic acid (C18:1) 35.0\% - 42.0\% and linoleic acid (C18:2) 16\% - 20\%.

Bodyweight gain and feed intake (FI) were recorded weekly by cage and FCR was computed at days 16 and 30. Analysis of variance was performed using the general linear model procedure of the Statistical Analysis System (SAS, 2002-2003) for a randomized complete block design with $2 \times 2 \times 2$ factorial arrangements. The data were tested for main effects (fat source, energy level and enzyme), two-way and three-way interactions. The experimental unit was the cage mean. Statistical significance was assessed at $(P$ $<0.05$ ). 
Table 1 Ingredient and nutrient composition of the experimental diets fed to broilers from days 1 to 30

\begin{tabular}{|c|c|c|c|c|}
\hline \multirow[b]{2}{*}{ Ingredients (\%) } & \multicolumn{2}{|c|}{ Starter } & \multicolumn{2}{|c|}{ Finisher } \\
\hline & $\begin{array}{c}\text { Low } \\
(\mathrm{T} 1, \mathrm{~T} 5)^{1}\end{array}$ & $\begin{array}{c}\text { Normal } \\
(\mathrm{T} 3, \mathrm{~T} 7)^{2}\end{array}$ & $\begin{array}{c}\text { Low } \\
(\mathrm{T} 1, \mathrm{~T} 5)^{1}\end{array}$ & $\begin{array}{c}\text { Normal } \\
(T 3, T 7)^{2}\end{array}$ \\
\hline Maize & 58.00 & 56.80 & 59.65 & 58.55 \\
\hline Soybean meal (48\% CP) & 36.10 & 36.10 & 34.00 & 34.00 \\
\hline Soybean oil or Kofat & 1.80 & 3.00 & 2.90 & 4.00 \\
\hline Salt & 0.30 & 0.30 & 0.30 & 0.30 \\
\hline Limestone & 0.72 & 0.72 & 0.64 & 0.64 \\
\hline Di calcium phosphate & 2.30 & 2.30 & 2.00 & 2.00 \\
\hline DL-methionine & 0.23 & 0.23 & 0.16 & 0.16 \\
\hline L-Lysine & 0.15 & 0.15 & - & - \\
\hline Vitamin-mineral premix ${ }^{3}$ & 0.30 & 0.30 & 3.00 & 3.00 \\
\hline Choline chloride premix, 60\% & 0.10 & 0.10 & 0.05 & 0.05 \\
\hline \multicolumn{5}{|l|}{ Calculated analysis } \\
\hline Metabolizable energy (MJ/kg) & 12.13 & 12.55 & 12.55 & 12.97 \\
\hline Crude protein (g/kg) & 220 & 220 & 210 & 210 \\
\hline Methionine (\%) & 0.55 & 0.55 & 0.47 & 0.47 \\
\hline Methionine + Cystine (\%) & 0.82 & 0.82 & 0.73 & 0.73 \\
\hline Lysine & 1.25 & 1.25 & 1.1 & 1.1 \\
\hline Calcium & 1.00 & 1.00 & 0.90 & 0.90 \\
\hline Available phosphorus & 0.45 & 0.45 & 0.40 & 0.40 \\
\hline
\end{tabular}

\footnotetext{
${ }^{1}$ Diets 2 and 6 had $0.05 \%$ Tomoko enzyme added.

${ }^{2}$ Diets 4 and 8 had $0.05 \%$ Tomoko enzyme added.

${ }^{3}$ Vitamin-mineral mix per $\mathrm{kg}$ of diet: $3.41 \mathrm{mg}$ retinyl acetate; $0.07 \mathrm{mg}$ cholecalciferol; $27.5 \mathrm{mg}$ DL- $\alpha$-tocopheryl acetate; $6 \mathrm{mg}$ menadione sodium bisulphate; $7.7 \mathrm{mg}$ riboflavin; $44 \mathrm{mg}$ niacin; $0.02 \mathrm{mg}$ cyanocobalamin; $496 \mathrm{mg}$ choline; $1.32 \mathrm{mg}$ folic acid; $4.82 \mathrm{mg}$ pyridoxine $\mathrm{HCl} ; 2.16 \mathrm{mg}$ thiamine mononitrate; $0.11 \mathrm{mg}$ D-biotin; $67 \mathrm{mg}$ manganese; $54 \mathrm{mg}$ zinc; $2 \mathrm{mg}$ copper; $0.5 \mathrm{mg}$ iodine; $75 \mathrm{mg}$ iron; $0.2 \mathrm{mg}$ selenium.
}

\section{Results}

Bird performance during the starter period is shown in Table 2. During this period, $\mathrm{FI}$ was not affected by fat source, energy level or enzyme supplementation or their interactions $(P>0.05)$. A two-way energy $x$ enzyme was significant for BWG $(P<0.005)$ such that TOM supplementation in the low energy level diet increased BWG by $20 \mathrm{~g}$, while TOM supplementation in the normal energy diet decreased BWG by $30 \mathrm{~g}$. Energy level of the diet affected BWG significantly $(P<0.01)$ : Chicks on the normal energy diet gained $20 \mathrm{~g}$ more than birds which received the low energy diet. A two-way energy $\mathrm{x}$ enzyme was significant for FCR $(P$ $<0.001$ ) such that enzyme supplementation to the low energy level diet improved FCR compared with unsupplemented diet (1.379 vs. 1.322), respectively, while TOM supplementation to the normal energy diet increased FCR compared with unsupplemented diet (1.260 vs. 1.334), respectively. Energy level of the diet affected FCR $(P<0.001)$ : chicks on the normal energy diet had a better FCR of 1.260 , compared to 1.334 for chicks that received the low energy diet.

Bird performance for the finisher period is shown in Table 3. None of the three-way interactions were significant for FI, BWG and FCR. However, FI was influenced by the energy level of the diet $(P<0.05)$ : birds on the low energy diet consumed $42 \mathrm{~g}$ more feed compared with those on the normal energy diet. Bodyweight gain was not influenced by any treatment $(P>0.05)$. On the other hand, energy $\mathrm{x}$ enzyme interaction was significant for FCR $(P<0.001)$. Enzyme (TOM) supplementation to the low energy diet improved FCR by $9.8 \%$ compared with the unsupplemented diet (1.584 vs. 1.704), respectively, while in the normal energy diet, TOM supplementation caused a drop in FCR by $1.2 \%$ compared with the unsupplemented diet (1.624 vs. 1.604), respectively. Two main effects, energy level and enzyme affected FCR significantly $(P<0.04 ; P<0.001)$, respectively. Birds that had received the normal energy level diet had a better FCR compared with the other group (1.614 vs. 1.643), respectively. On the other hand, TOM supplementation improved FCR by $3 \%$ (1.604 vs. 1.653), respectively. 
Table 2 Feed intake (FI), bodyweight gain (BWG) and feed conversion ratio (FCR) at day 16 of broiler chickens given the experimental diets

\begin{tabular}{|c|c|c|c|c|c|c|}
\hline Diet & $\begin{array}{c}\text { Fat } \\
\text { source }\end{array}$ & $\begin{array}{c}\text { Energy } \\
\mathrm{MJ} / \mathrm{kg}\end{array}$ & $\begin{array}{c}\text { Enzyme } \\
(\%)\end{array}$ & $\begin{array}{l}\mathrm{FI} \\
(\mathrm{g})\end{array}$ & $\begin{array}{c}\text { BWG } \\
\text { (g) }\end{array}$ & $\begin{array}{l}\text { FCR } \\
\text { (g/g) }\end{array}$ \\
\hline 1 & Soy oil & 12.13 & 0 & 637 & 462 & 1.377 \\
\hline 2 & Soy oil & 12.13 & 0.05 & 646 & 485 & 1.330 \\
\hline 3 & Soy oil & 12.55 & 0 & 652 & 520 & 1.253 \\
\hline 4 & Soy oil & 12.55 & 0.05 & 631 & 486 & 1.300 \\
\hline 5 & Kofat & 12.13 & 0 & 660 & 477 & 1.381 \\
\hline 6 & Kofat & 12.13 & 0.05 & 649 & 494 & 1.315 \\
\hline 7 & Kofat & 12.55 & 0 & 647 & 510 & 1.268 \\
\hline 8 & Kofat & 12.55 & 0.05 & 661 & 484 & 1.368 \\
\hline SEM & & & & 17.6 & 10.8 & 0.024 \\
\hline$P$ value & & & & NS & NS & NS \\
\hline \multicolumn{7}{|l|}{ Source } \\
\hline Soy oil & & & & 642 & 489 & 1.315 \\
\hline Kofat & & & & 655 & 491 & 1.332 \\
\hline SEM & & & & 8.9 & 5.4 & 0.012 \\
\hline$P$ value & & & & NS & NS & NS \\
\hline \multicolumn{7}{|l|}{ Energy } \\
\hline Low & & & & 648 & 480 & 1.350 \\
\hline Normal & & & & 648 & 500 & 1.297 \\
\hline SEM & & & & 8.9 & 5.4 & 0.012 \\
\hline$P$ value & & & & NS & 0.01 & 0.005 \\
\hline \multicolumn{7}{|l|}{ Enzyme } \\
\hline Without & & & & 649 & 493 & 1.319 \\
\hline With & & & & 647 & 487 & 1.328 \\
\hline SEM & & & & 8.9 & 5.4 & 0.012 \\
\hline$P$ value & & & & NS & NS & NS \\
\hline \multicolumn{7}{|c|}{ Energy $x$ enzyme } \\
\hline & & 12.13 & 0 & 648 & 470 & 1.379 \\
\hline & & 12.13 & 0.05 & 647 & 490 & 1.322 \\
\hline & & 12.55 & 0 & 646 & 515 & 1.260 \\
\hline & & 12.55 & 0.05 & 646 & 485 & 1.334 \\
\hline SEM & & & & 12.6 & 7.7 & 0.017 \\
\hline$P$ value & & & & NS & 0.005 & 0.001 \\
\hline
\end{tabular}

Cumulative bird performance for the period from 1 to 30 days of age is shown in Table 4. Feed intake was not influenced by fat source, energy level, enzyme supplementation or their interactions $(P>0.05)$. On the other hand, BWG was not influenced by any main factor. However, energy $x$ enzyme interaction was significant for BWG and FCR $(P<0.01 ; P<0.001)$, respectively. TOM supplementation to the low energy diet increased BWG by $45 \mathrm{~g}$ and improved FCR by $6.6 \%$ compared with unsupplemented diet. However, TOM supplementation to the normal energy diet decreased BWG by $41 \mathrm{~g}$ and caused a drop in FCR by $4.3 \%$. Feed conversion ratio was influenced by the energy level $(P<0.001)$ and TOM supplementation $(P<0.05)$ as a main effect factors. No three-way interactions were detected for all parameters measured for the cumulative period. 
Table 3 Feed intake (FI), bodyweight gain (BWG) and feed conversion ratio (FCR) at day 30 of broiler chickens given the experimental diets

\begin{tabular}{|c|c|c|c|c|c|c|}
\hline Diet & $\begin{array}{c}\text { Fat } \\
\text { source }\end{array}$ & $\begin{array}{c}\text { Energy } \\
\mathrm{MJ} / \mathrm{kg}\end{array}$ & $\begin{array}{c}\text { Enzyme } \\
(\%)\end{array}$ & $\begin{array}{l}\mathrm{FI} \\
(\mathrm{g})\end{array}$ & $\begin{array}{l}\text { BWG } \\
\text { (g) }\end{array}$ & $\begin{array}{l}\text { FCR } \\
\text { (g/g) }\end{array}$ \\
\hline 1 & Soy oil & 12.55 & 0 & 1434 & 846 & 1.697 \\
\hline 2 & Soy oil & 12.55 & 0.05 & 1394 & 881 & 1.583 \\
\hline 3 & Soy oil & 12.97 & 0 & 1381 & 854 & 1.617 \\
\hline 4 & Soy oil & 12.97 & 0.05 & 1416 & 883 & 1.605 \\
\hline 5 & Kofat & 12.55 & 0 & 1464 & 855 & 1.711 \\
\hline 6 & Kofat & 12.55 & 0.05 & 1380 & 871 & 1.585 \\
\hline 7 & Kofat & 12.97 & 0 & 1374 & 863 & 1.591 \\
\hline 8 & Kofat & 12.97 & 0.05 & 1336 & 814 & 1.643 \\
\hline SEM & & & & 26.9 & 18.3 & 0.02 \\
\hline$P$ value & & & & NS & NS & NS \\
\hline \multicolumn{7}{|l|}{ Source } \\
\hline Soy oil & & & & 1406 & 866 & 1.625 \\
\hline Kofat & & & & 1388 & 851 & 1.632 \\
\hline SEM & & & & 13.5 & 9.2 & 0.01 \\
\hline$P$ value & & & & NS & NS & NS \\
\hline \multicolumn{7}{|l|}{ Energy } \\
\hline Low & & & & 1418 & 863 & 1.643 \\
\hline Normal & & & & 1376 & 854 & 1.614 \\
\hline SEM & & & & 13.5 & 9.1 & 0.01 \\
\hline$P$ value & & & & 0.03 & NS & 0.04 \\
\hline \multicolumn{7}{|l|}{ Enzyme } \\
\hline Without & & & & 1413 & 845 & 1.653 \\
\hline With & & & & 1382 & 862 & 1.604 \\
\hline SEM & & & & 13.5 & 9.1 & 0.01 \\
\hline$P$ value & & & & NS & NS & 0.001 \\
\hline \multicolumn{7}{|c|}{ Energy $x$ enzyme } \\
\hline & & 12.55 & 0 & 1449 & 850 & 1.704 \\
\hline & & 12.55 & 0.05 & 1387 & 876 & 1.584 \\
\hline & & 12.97 & 0 & 1377 & 858 & 1.604 \\
\hline & & 12.97 & 0.05 & 1376 & 848 & 1.624 \\
\hline SEM & & & & 19.1 & 12.9 & 0.01 \\
\hline$P$ value & & & & NS & NS & 0.001 \\
\hline
\end{tabular}

\section{Discussion}

The results revealed significant energy $x$ enzyme interactions in BWG and FCR at 30 day of age, which could be explained by a difference in magnitude or response. Birds on the low energy level diet responded positively to TOM supplementation, while those that had the normal energy diet responded negatively to TOM. The beneficial effect of TOM in the diet was best when TOM was added to the low energy diet. The improvement in FCR could be explained in part by the improvement in BWG that occurred as a result of TOM. Body weight gain for the low energy diet group plus TOM was restored and comparable with that of the normal energy diet without TOM, suggesting that the improvement in nutrient utilization brought about by TOM supplementation completely compensated for the reduced energy content. This result offers potential to reduce diet cost commensurate with no losses in production. 
Table 4 Cumulative feed intake (FI), liveweight gain (BWG) and feed conversion ratio (FCR) of broiler chickens over the trial period of 30 days

\begin{tabular}{|c|c|c|c|c|c|c|}
\hline Diet & $\begin{array}{c}\text { Fat } \\
\text { source }\end{array}$ & Energy & $\begin{array}{c}\begin{array}{c}\text { Enzyme } \\
(\%)\end{array} \\
\end{array}$ & $\begin{array}{l}\mathrm{FI} \\
(\mathrm{g})\end{array}$ & $\begin{array}{c}\text { BWG } \\
\text { (g) }\end{array}$ & $\begin{array}{l}\text { FCR } \\
(\mathrm{g} / \mathrm{g}) \\
\end{array}$ \\
\hline 1 & Soy oil & low & 0 & 2072 & 1308 & 1.584 \\
\hline 2 & Soy oil & low & 0.05 & 2039 & 1366 & 1.492 \\
\hline 3 & Soy oil & normal & 0 & 2033 & 1375 & 1.479 \\
\hline 4 & Soy oil & normal & 0.05 & 2047 & 1368 & 1.493 \\
\hline 5 & Kofat & low & 0 & 2124 & 1334 & 1.593 \\
\hline 6 & Kofat & low & 0.05 & 2029 & 1365 & 1.487 \\
\hline 7 & Kofat & normal & 0 & 2020 & 1373 & 1.471 \\
\hline 8 & Kofat & normal & 0.05 & 1997 & 1298 & 1.540 \\
\hline SEM & & & & 32.5 & 23.5 & 0.01 \\
\hline$P$ value & & & & NS & NS & NS \\
\hline \multicolumn{7}{|l|}{ Source } \\
\hline Soy oil & & & & 2043 & 1355 & 1.513 \\
\hline Kofat & & & & 2048 & 1343 & 1.523 \\
\hline SEM & & & & 16.3 & 11.7 & 0.008 \\
\hline$P$ value & & & & NS & NS & NS \\
\hline \multicolumn{7}{|l|}{ Energy } \\
\hline Low & & & & 2066 & 1344 & 1.539 \\
\hline Normal & & & & 2025 & 1354 & 1.497 \\
\hline SEM & & & & 16.3 & 11.7 & 0.008 \\
\hline$P$ value & & & & NS & NS & 0.001 \\
\hline \multicolumn{7}{|l|}{ Enzyme } \\
\hline Without & & & & 2063 & 1348 & 1.532 \\
\hline With & & & & 2028 & 1350 & 1.504 \\
\hline SEM & & & & 16.3 & 11.7 & 0.008 \\
\hline$P$ value & & & & NS & NS & 0.03 \\
\hline \multicolumn{7}{|c|}{ Energy $x$ enzyme } \\
\hline & & low & 0 & 2098 & 1321 & 1.588 \\
\hline & & low & 0.05 & 2034 & 1366 & 1.490 \\
\hline & & normal & 0 & 2027 & 1374 & 1.475 \\
\hline & & normal & 0.05 & 2022 & 1333 & 1.518 \\
\hline SEM & & & & 23.0 & 16.6 & 0.01 \\
\hline$P$ value & & & & NS & 0.01 & 0.001 \\
\hline
\end{tabular}

The improvement in BWG of broilers that received TOM supplemented diets could be ascribed to increases in protein and energy retention. Dänicke et al. (1997b) found that fat digestibility in broilers was improved by enzymes in two fat sources (soybean oil and beef tallow) but protein digestibility and $\mathrm{AME}_{\mathrm{N}}$ values were significantly improved by enzymes only in a tallow diet. It was reported that enzymes reduce the negative effects of NSPs and improve the digestion of nutrients in poultry diets. Hydrolysis of NSPs reduces the viscous properties of $\beta$-glucan and pentosans, releases some available monosaccharides and in part, eliminates the nutrient encapsulating effect of the cell wall (Bedford, 1993). It has been reported that enzyme supplementation to corn-soy diets improved growth performance significantly in broilers (Gracia et al., 2003; Saleh et al., 2006; Abudabos, 2012). Preston et al. (2001) reported a 2\% improvement in FCR as a result of the addition of an enzyme, Avizyme 1300.

The positive effect of fats on live performance of broilers is well documented (Griffiths et al., 1977). 
The growth stimulating property of fats is not just a result of their high energy value. Chicks fed diets with SBO or corn oil consumed more ME than chicks fed comparable diets that had a low fat content (Carew et al., 1963; Pesti et al., 2002). The value of the various fats and oils is entirely dependent on their ME contents, and the ME content of the fat depends on their digestibility and absorption (Pesti et al., 2002). In this experiment the birds that received the two sources of fat had similar live performances. This suggests that the two fat sources have similar digestibility. A similar response was obtained by Valencia et al. (1993) who reported that there were no effects of the sources of oil (refined palm oil, palm oil, corn oil and poultry fat) on BWG and FCR in broilers. The result is congruent with previous findings of Abudabos (2013), who reported that birds that received KOF or SBO responded equally.

Owing to the high cost of feed ingredient for poultry, especially dietary energy, it is important to continually evaluate the source as well as the level of energy in the diets (Pesti et al., 2002). KOF is a cheaper source of fat than SBO or corn oil. Fat supplementation is considered more cost effective over the finisher period than the starter period because of increased digestibility of fat, improved dietary ME and increased feed intake of the birds during the finisher period (Wiseman \& Salvador, 1989).

\section{Conclusions}

The results of this study indicated that the replacement of SBO with KOF resulted in comparable performance in terms of BWG, FI and FCR, but using KOF as the fat source could result in reduced overall feed cost, since it is a cheaper commercial fat blend than SBO. TOM at the rate recommended by the manufacturer $(0.05 \%)$ restored the nutritional value in the low energy diet. Based on the results obtained from this experiment and in order to lower the feed cost, it is recommended that KOF could be fed as a fat source level combined with TOM supplementation to broilers on a low-energy diet.

\section{Acknowledgment}

The authors would like to extend their sincere appreciation to the Deanship of Scientific Research at King Saud University for its funding of this research through Research Group Project No., RGP-VPP-273.

\section{References}

Abudabos, A., 2013. Feeding alternative source of fat to broilers. Res. 5 (10), 84-87.

Abudabos, A., 2012. Effect of enzyme supplementation to normal and low density broiler diets based on corn-soybean meal. Asian J. Anim. Vet. Sci. Adv. 7, 139-148.

Baião, N.C. \& Lara, L.J.C., 2005. Oil and fat in broiler nutrition. Braz. J. Poult. Sci. 7, 129-141.

Barbour, G.W., Farran, M.T., Usayran, N.N., Darwish, A.H. \& Ashkarian, V.M., 2006. Effect of soybean oil supplementation to low metabolizable energy diets on production parameters of broiler chickens. J. Appl. Poult. Res. 15, 190-197.

Bedford, M., 1993. Mode of action of feed enzymes. J. Appl. Poult. Res. 2, 85-92.

Café, M.B., Borges, C.A., Fritis, C.A. \& Waldroup, P.W., 2002. Avizyme improves performance of broilers fed corn-soybean meal-based diets. J. Appl. Poult. Res. 11, 20-33.

Carew Jr., L.B., Nesheim, M.C. \& Hill, F.W., 1963. The relationship of dietary energy level and density to the growth response of chicks to fats. Poult. Sci. 42, 710-718.

Dänicke, S., Simon, O., Jeroch, H. \& Bedford, M., 1997a. Interactions between dietary fat type and xylanase supplementation when rye-based diets are fed to broiler chickens 1 . Physico-chemical chyme features. Br. Poult. Sci. 38, 537-545.

Dänicke, S., Simon, O., Jeroch, H. \& Bedford, M., 1997b. Interactions between dietary fat type and xylanase supplementation when rye-based diets are fed to broiler chickens 2 . Performance, nutrient digestibility and the fat-soluble vitamin status of livers. Br. Poult. Sci. 38, 546-556.

Dänicke, S., Jeroch, H., Bottcher, W. \& Simon, O., 2000. Interactions between dietary fat type and enzyme supplementation in broiler diets with high pentosan contents: effects on precaecal and total tract digestibility of fatty acids, metabolizability of gross energy, digesta viscosity and weights of small intestine. Anim. Feed Sci. Technol. 84, 279-294.

Fascina, V.B., Carrijo, A.S., Souza, K.M.R., Garcia, A.M.L., Kiefer, C. \& Sartori, J.R.I., 2009. Soybean oil and beef tallow in starter broiler diets. Braz. J. Poult. Sci. 11, 249-256.

Gracia, M.I., Aranibar, M.J., Lazaro, R., Medel, P. \& Mateos, G.C., 2003. Alpha-amylase supplementation of broiler diets based on corn. Poult. Sci. 82, 436-442.

Griffiths, L., Leeson, S. \& Summers, J.D., 1977. Influence of energy system and level of various fat sources on performance and carcass composition of broiler. Poult. Sci. 56, 1018-1026.

Langhout, D.J., Schutte, J.B., Geerse, C., Kies, A.K., De Jong, J. \& Verstegen, M.W.A., 1997. Effects on chick performance and nutrient digestibility of an endo-xylanase added to a wheat- and rye-based diet in relation to fat source. Br. Poult. Sci. 38, 557-563. 
Marquardt, R.R., 1997. Enzyme enhancement of the nutritional value of cereals: role of viscous, watersoluble, nonstarch polysaccharides in chick performance. In: Enzyme in Poultry and Swine Nutrition. Eds: Marquardt, R.R. \& Han, Z., International Development Research Centre, Ottawa, Canada. pp. 5-17.

Monfaredi, A., Rezaei, M. \& Sayyahzadeh, H., 2011. Effect of supplemental fat in low energy diets on some blood parameters and carcass characteristics of broiler chicks. S. Afr. J. Anim. Sci. 41, 24-32.

Pack, M. \& Bedford, M., 1997. Feed enzymes for corn and soybean broiler diets. Wrld's Poult. 13, 87-93.

Pesti, G.M., Bakalli, R.I., Qiao, M. \& Sterling, K.G., 2002. Comparison of eight grades of fat as broiler feed ingredients. Poult. Sci. 81, 382-390.

Preston, C.M., McCracken, K.J. \& Bedford, M.R., 2001. Effect of wheat content, fat source and enzyme supplementation on diet metabolisability and broiler performance. Br. Poult. Sci. 42, 625-32.

Saleh, F., Yamamoto, M., Tahir, M., Ohtsuka, A. \& Hayashi, K., 2006. A new natural feed additive for broiler chickens. Poultry Science Association Annual Meeting. Edmonton, Canada. pp. 36-54.

SAS, 2002-2003. SAS Users Guide: Statistics. Version 9.1.3. SAS Institute, Cary, N.C., USA.

Valencia, M.E., Watkins, S.E., Waldroup, A.L. \& Waldroup, P.W., 1993. Utilization of crude and refined palm and palm kernel oils in broiler diets. Poult. Sci. 72, 2200-2215.

Waldroup, A.L., Watkins, S.E. \& Saleh, E.A., 1995. Comparison of two blended animal-vegetable fats having low or high free fatty acid content. J. Appl. Poult. Res. 4, 41-48.

Ward, A.T. \& Marquardt, R.R., 1983. The effect of saturation, chain length of pure triglycerides and age of bird on the utilization of rye diets. Poult. Sci. 62, 1054-1062.

Wiseman, J. \& Salvador, F., 1989. Influence of age, chemical composition and rate of inclusion on the apparent metabolizable energy of fats fed to broiler chicks. Br. Poult. Sci. 30, 653-662.

Wiseman, J., Salvador, F. \& Craigon, J., 1991. Prediction of the apparent metabolizable energy content of fats fed to broiler chickens. Poult. Sci. 70, 1527-1533. 